\title{
Colour terms in Russian: reflections of typological constraints in a single language*
}

\author{
GREVILLE CORBETT AND GERRY MORGAN \\ University of Surrey'
}

(Received 7 February 1987; revised 21 May 1987)

\section{INTRODUCTION}

One of the milestones in typological studies is Berlin \& Kay's (1969) account of basic colour terms, which has produced a steady stream of research of various types. Berlin \& Kay summarized their work as follows.

In sum, our two major findings indicate that the referents for the basic color terms of all languages appear to be drawn from a set of eleven universal perceptual categories, and these categories become encoded in the history of a given language in a partially fixed order (1969:4-5).

Given a language which has colour terms for each of the eleven categories, the question arises as to whether Berlin \& Kay's typology will still be reflected there. We believed that colour terms higher on the Berlin \& Kay hierarchy (therefore whose presence is a prerequisite for the presence of lower terms both diachronically and synchronically) would turn out to be more central to the lexical structure even when all eleven colour categories were represented by colour terms. We investigated the notion of centrality in two distinct ways: first we examined the forms derived from colour terms, and secondly we compared the frequency of occurrence of the different colour terms in a variety of sources. Both tests reveal regularities which can be predicted from the Berlin \& Kay results. What is particularly interesting, however, is the case where the two tests give different results, since this provides evidence for the internal reconstruction of the colour vocabulary. We first review Berlin \& Kay's work briefly (Section 2), and present the colour terms of Russian (Section 3). After these preliminaries, we describe the morphological evidence (Section 4), then move on to the word-frequency data (Section 5) and finally discuss the significance of our results (Section $6)$.

[*] We are grateful to Professor P. Kay for providing a copy of Daly (MS) and to Dr I. Forbes, Dr A. Kimber, Professor H. McGurk, Dr Gunther Senft and Dr A. Tarrant for help of various kinds. Our thanks also go to two anonymous referees and to Nigel Vincent for useful comments. This research was funded in part by the Leverhume Trust, whose support is gratefully acknowledged. 


\section{THE BERLIN \& KAY HIERARCHY}

Berlin \& Kay's 1969 study of 98 languages provided arguments for the existence of semantic universals in the field of colour terminology. ${ }^{1}$ They concluded that:

If a language encodes fewer than eleven basic color categories, then there are strict limitations on which categories it may encode. The distributional restrictions of color terms across languages are:

(1) All languages contain terms for white and black.

(2) If a language contains three terms, then it contains a term for red.

(3) If a language contains four terms, then it contains a term for either green or yellow (but not both).

(4) If a language contains five terms, then it contains terms for both green and yellow.

(5) If a language contains six terms, then it contains a term for blue.

(6) If a language contains seven terms, then it contains a term for brown.

(7) If a language contains eight or more terms, then it contains a term for purple, pink, orange, grey, or some combination of these (Berlin \& Kay, I969:2-3).

These rules can be summarized in the following hierarchy (Berlin \& Kay I969: 4):

$$
\left[\begin{array}{l}
\text { white } \\
\text { black }
\end{array}\right]<[\text { red }]<\left[\begin{array}{l}
\text { green } \\
\text { yellow }
\end{array}\right]<[\text { blue }]<[\text { brown }]<\left[\begin{array}{l}
\text { purple } \\
\text { pink } \\
\text { orange } \\
\text { grey }
\end{array}\right]
$$

This hierarchy may be seen as constraining the possible sets of colour terms in human languages; it can also be considered in diachronic terms, since a change in the colour-term system must be from one state sanctioned by the hierarchy to another.

Berlin and Kay also suggest that children may develop a command of colour terms on the same model (I969: 108-9). This idea is discussed in Heider (I97I : 454-455), in Cruse (1977), and more recently in Andrick \& Tager-Flusberg (1986). Senft's study of Kilivila (forthcoming) also includes

[1] For the difficulties of analysing the semantics of colour terms, see Wilson (1972) and Frumkina $(1978,1979)$. For a rather different approach to colour terms see Mathiot (1979). For the measurement and description of colour, see Rabkin, (1956:1-26), Judd \& Wyszecki (1963:202w313) and Wright (1969: 154-193). The philosophical analysis of colour has been the subject of lively debate: Putnam (1956, 1957) and Pap (1957). Historical notes are given by Pelevina (1962); she reports that Thurnwald (1922: 168) gave black, white and red as the first colour terms; he is therefore a forerunner of Berlin \& Kay. 


\section{COLOUR TERMS IN RUSSIAN}

interesting data on the colour terms of children of different ages as evidence for language change in progress. A further aspect of colour-term systems that has generated interest is their role in memory (see Burnham \& Clark, I955; Heider, 1972; and Heider \& Olivier, 1972). Since Berlin \& Kay's initial study, a number of modifications have been made to the hierarchy of basic terms (see, for example, Kay, 1975, Witkowski \& Brown, 1977 and Kay \& McDaniel, 1978). However, for the present study the original hierarchy is a convenient starting point.

\section{THE COLOUR TERMS OF RUSSIAN}

The normal method by which hypotheses are formulated as to the basic colour terms in a given language is the elicitation interview (Kay \& McDaniel, 1978: 613). This is not a straightforward technique. Those who have carried out informant work on Russian disagree on the inventory of basic terms. Furthermore, establishing the set of basic terms for Russian is of particular interest, since it appears to have a most unusual pattern. In other respects, Russian has been well researched, and there is an impressive range of basic reference works available (notably dictionaries of various types). We decided to start with these in the belief that the fact that they were not primarily concerned with colour would make our data more objective, although naturally, published data from informant work is also taken into account. Furthermore, while our main interest was to find ways of ranking different colour terms (to verify the hypothesis that such ranking would be a reflexion of the Berlin \& Kay hierarchy), any method of ranking in which indisputable basic colour terms occur might then be considered as a way of resolving dubious cases.

Our first concern, therefore, was to ensure that all the basic colour terms were included. It did not matter if some non-basic terms were also investigated; these might provide useful comparisons when analysing the less clear cases. A natural place to start is the list for Russian provided by Slobin and given in Berlin \& Kay (1969: 98-99). For reasons which will become clear later, we are not fully satisfied with this list. We decided therefore to use dictionaries to supplement Slobin's list. As a first step, we looked up the equivalents of the English terms in the following English-Russian dictionaries: Dictionary of Spoken Russian (1958), Müller (1965), Gal'perin (1977), Wilson, (1982) and Falla (1984). As the resulting list was rather unwieldy, we eliminated items which were clearly not basic colour terms - for example, those with limited distribution (e.g. poetical), those which are not primarily colour terms (e.g. zagorelyj 'sunburnt', given as an entry for 'brown') and those occurring in special collocations. The criteria for basicness are given in Berlin \& Kay (1969:4-6) and are discussed in Section 6.1 below. The list was still an imposing one; we therefore checked back in the following Russian-English dictionaries: Dictionary of Spoken Russian 
(1958), Smirnitsky (1965) and Wheeler (1984). Items which were not backtranslated as basic colour terms were eliminated at this stage. ${ }^{2}$

Let us then turn to the colour terms proposed by Slobin in Berlin \& Kay (1969: 98-99); we reorder the list slightly and use a different transliteration scheme. For the terms higher on the hierarchy there is no problem. They are čërnyj 'black', belyj 'white', krasnyj 'red', zelënyj 'green' and žëltyj' yellow'. The next two terms are sinij 'dark blue' and goluboj 'light blue'. To date a major interest in Russian of those working on colour terms has been the existence of these two terms, both of which appear to be basic, where one is expected. Naturally we retain both in our list. Slobin next gives koričnevyj 'brown'. All five English-Russian dictionaries consulted give this term; three also give buryj as 'brown' (though Falla (1984) qualifies it as 'grey-brown'). Checking Russian-English dictionaries, we find that Smirnitsky (1965) and Wheeler (I984) translate buryj as 'brown'; we therefore add it to our list. ${ }^{3}$ Slobin's suggestions of seryj 'grey' and rozovyj 'pink' are undisputed.

The remaining two terms are more contentious. Slobin gives kirpičnyj 'orange'. This adjective is derived from the noun kirpič 'brick' and its primary meaning is 'pertaining to brick' found in expressions such as kirpičnyj zavod 'brick factory'. Its colour meaning is secondary, and we should be suspicious about its claim to be a basic colour term bearing in mind one of the Berlin \& Kay criteria, namely that 'color terms that are also the name of an object characteristically having that colour are suspect' (1969: 6); while it is not exactly the 'name of an object', its derivation is clear. Furthermore, there is a more obvious term-all five English-Russian dictionaries give oranževyj 'orange'. Slobin may have avoided this term as being a borrowing. It is not, however, a particularly recent one. Furthermore, it has been assimilated by the addition of the adjectival suffix ov/ev. Note too that it has no association with an object; the fruit in Russian is apel'sin 'orange'. We believe that Slobin was simply mistaken; there is no doubt that the basic term in Modern Russian is oranževyj, and this is the one we shall investigate. $^{\mathbf{4}}$

Finally, we come to the most complex case. Slobin gives purpurnyj 'purple'. However, as we shall see, there is some disagreement here. Daly (MS: 17) suggests that there is no basic term for purple in Russian ${ }^{5}$ we had

[2] For example the entry for 'red' in Muller (1965) includes rumjanyj in the Russian equivalents. The translations of rumjanyj in Snirnitsky (1965) and Wheeler (1984) are 'rosy, rubicund, ruddy". On this basis rumjanyj was eliminated.

[3] See Polubichenko \& Shkhvatsabaja (1985:57) for collocations in which koričnevyj is not acceptable.

[4] Frumkina \& Mixeev (1983:55) take oranževyj to be basic and suggest that the use of kirpičnyj is an error; Daly (MS: 19) also uses oranževyj.

[5] He considers fioletovyj, hlovyj and sirenevyj, and finds purpurovyj to be 'bookish'. We include all of these except sirenevyj 'lilac-coloured', since this appears not to be a basic term, being derived from siren' 'lilac' (see Berlin \& Kay, 1967: 6, and Section 6.1 below). For comparison with data in later sections, note that it has only two morphological 


\section{COLOUR TERMS IN RUSSIAN}

come independently to a similar tentative conclusion. This possibility makes Russian doubly interesting: it appears to have an 'extra' term for blue, even though 'missing' a term for purple. We shall therefore include in our study all the terms which have any claim to be a basic term for purple, in order to demonstrate the point. To avoid missing any possible candidates, we again consulted dictionaries. Table I shows the different terms offered for 'purple' in five English-Russian dictionaries.

\begin{tabular}{cllll}
\hline $\begin{array}{l}\text { Dictionary of } \\
\text { Spoken Russian (1958) }\end{array}$ & $\begin{array}{l}\text { Müller } \\
(1965)\end{array}$ & $\begin{array}{l}\text { Gal'perin } \\
(1977)\end{array}$ & $\begin{array}{l}\text { Wilson } \\
(1982)\end{array}$ & $\begin{array}{l}\text { Falla } \\
(1984)\end{array}$ \\
\hline lilovyj & $\begin{array}{l}\text { purpurnyj } \\
\text { bagrovyj } \\
\text { fioletovyj }\end{array}$ & $\begin{array}{l}\text { foletovyj } \\
\text { lilovyj } \\
\text { purpurnyj } \\
\text { purpurovyj } \\
\text { bagrovyj }\end{array}$ & $\begin{array}{l}\text { floletovyj } \\
\text { lilovyj }\end{array}$ & $\begin{array}{l}\text { purpurnyj } \\
\text { lilovyj } \\
\text { fioletovyj } \\
\text { bagrovyj }\end{array}$ \\
& & & \\
\hline
\end{tabular}

Table I

Entries for English purple

Not only is there no agreement on the first term to be given, there is no single Russian term which is found in all five entries.

When we check the five alternatives in Russian-English dictionaries we obtain the data again in Table 2.

\begin{tabular}{lcll}
\hline Russian term & $\begin{array}{c}\text { Dictionary of } \\
\text { Spoken Russion (1958) }\end{array}$ & \multicolumn{1}{c}{$\begin{array}{c}\text { Smirnitsky } \\
(1965)\end{array}$} & $\begin{array}{l}\text { Wheeler } \\
(1984)\end{array}$ \\
\hline bagrovyj & no entry & $\begin{array}{l}\text { crimson, (with fioletovyj } \\
\text { tinge) purple }\end{array}$ & $\begin{array}{l}\text { crimson, } \\
\text { purple } \\
\text { fioletovyj }\end{array}$ \\
lilovyj & violet, purple & $\begin{array}{l}\text { violet } \\
\text { lilac, }\end{array}$ & violet \\
purpurnyj & violet & lilac, \\
purpurovyj & no entry & purple & violet \\
\hline
\end{tabular}

Table 2

English equivalents of Russian entries for purple

The table reveals a confused situation. Each Russian term is translated as 'purple' by at least one lexicographer. While purpurnyj (as in Slobin) and purpurovyj might appear to be the best candidates, the comment in Smirnitsky may be read as suggesting that bagrovyj is wider in scope. (Bagrovyj has an alternative bagrjanyj marked as poetical, which we therefore omit. ${ }^{6}$ In view

[6] Vasilevič (1983: 10) is critical of the available dictionaries for their renderings of English purple and claims that translators are misled into using purpurnyj. In his data (literary texts), purpurny i is used in 55 per cent of cases. foletouvi which he considers hest is 
of the uncertainty, we shall include all five terms in our investigation. For simplicity we shall gloss them as follows: bagrovyj 'crimson', foletovyj 'violet ', lilovyj 'lilac', purpurnyj and purpurovyj 'purple'; however, it should be borne in mind that all are contenders for the 'purple slot'. It is worth stressing, in advance of our conclusions, that 'purple' for both purpumyj and purpurovyj is often a mistranslation; both typically denote a redder hue than English purple.

We thus end up with a longer list than Slobin's, with buryj as well as koričnevyj for brown, oranževyj for orange, and the five terms just discussed for the purple area. As far as we are aware there is no colour term with any reasonable claim to be a basic term which is not on our list. We can therefore be confident that we have all (but not only) the basic colour terms of Russian.

\section{EVIDENCE FROM DERIVATIONAL MORPHOLOGY}

We now consider whether the Berlin \& Kay hierarchy will be reflected in derivational morphology. This idea stems from Dixon (1982:23-24), who makes the following claim:

the colour term hierarchy is rather strict, and it is unlikely that a word low in the hierarchy would have morphological/syntactic possibilities that a higher word lacks.

In order to correlate the derivational possibilities of the Russian colour terms with their position in the hierarchy, ${ }^{7}$ we used the derivational dictionary by Worth et al. (1970). They based their dictionary on a standard reference work of contemporary Russian, the one-volume orthographic dictionary by Ožegov \& Śapiro (I959). We decided to adhere to the inventory and analysis of Worth et al., rather than supplement it with other materials and our own analysis, so that there could be no chance of our biasing the results. The advantage of Worth $e t$ al. is that they arrange the data in alphabetical order of root morphemes. All words derived, for example, from belyj 'white', whatever prefix or suffix may be present, are arranged under the root morpheme bel, as follows:

in only 9 per cent of cases. On the other hand, Penova (Agoston, 1982), in her translation of Agoston (1979) regularly chooses purpurnyj to translate purple. The closeness of bagrovyj, purpurnyj and purpurovyj is clearly illustrated by Alimpieva (1986: 78-79).

[7] After completing the morphological analysis we discovered that Moskovič (1969: 39-4I) had investigated the morphology of colour terms in Ukrainian (before the publication of Berlin \& Kay's book). Though he considers less affixes than in our Table 3, the terms with more derivatives tend to be those higher on the Berlin \& Kay scale. He investigates other measures both for Ukrainian and English, with interesting results. He also gives data on the formation of compounds involving colour terms in Russian (1969: 133-137). For data on the morphology of French colour terms see Meunier (1978: 169-173) and Lacroix (1978: 18I-185). 
COLOUR TERMS IN RUSSIAN

$$
\begin{array}{cl}
\text { snež n } o-\text { bel yj } & \text { 'as white as snow' } \\
\text { jar k o-bel yj } & \text { 'bright white' } \\
\text { bel 'e } & \text { 'linen, underwear' } \\
\text { bel 'ev oj } & \text { 'pertaining to linen' }
\end{array}
$$

Table 3 was constructed by charting the distribution of every affix associated with a colour term by Worth et al. Note that items were included whether or not the notion of colour is retained. Thus bel' $\ddot{e}$ in the list above means 'linen' or 'underwear'. As Wade ( $1985: 5 \mathrm{I}$ ) points out, this need no longer be white, as čërnoe bel' $\ddot{e}$ 'black underwear' occurs in modern Russian. ${ }^{8}$

In the table, each column or combination of columns is based on a single affix, combination of affixes or other compounding form. For example, the suffix -ovat- (corresponding to ish in English colour terms), together with its adjectival ending $-y j$, was found to occur with i i basic colour roots (column 1), while the suffix -izna (abstract noun form) was found with only four colour roots (column I8). The basic colour roots were arranged in the order suggested by Berlin \& Kay. Items which occur at the same point on the Berlin \& Kay hierarchy, such as white (belyj) and black (čërnyj), are bracketed together and arranged in order of the total number of items found by Worth et al. Where two Russian colour terms correspond to one basic colour term as set out by Berlin \& Kay (e.g. sinij and goluboj for blue, discussed in Section I) these are also arranged in order of ToTAL number of derivations in the Worth et al. study.

The vertical columns were arranged in descending order of the number of items contained in them. Thus column (2) contains I I items, column (24) only four. Where two or more columns contained the same number of items (e.g. 16-24 all have four items) we gave primacy to the column containing the least basic colour root. For example, column (16) descends as far as rozovyj, and is therefore placed before column (17), which descends only as far as seryj. If two columns extended equally far down Berlin \& Kay's scale, the one containing the more basic colour root was put first. For example, columns (2I) and (22) both reach as far as simij, but (2I) contains a belyj term. In order to keep the table to a manageable size, we imposed the criterion that each column should contain at least four items; affixes occurring with less than four items do not, therefore, appear as a column in the table, but they are included in the final total column. A further economy was achieved in the creation of columns: where two or more associated affixes were found to have identical distribution, we incorporated them into a single column. This can be seen in columns (4) and (14).

At this stage it is perhaps worth working through one or two columns of the table, so as to demonstrate how they work in practice. The first column, for

[8] Similarly golub' 'dove ' is included, even though its semantics are different from other items in column (9). 
GREVILLE CORBETT AND GERRY MORGAN

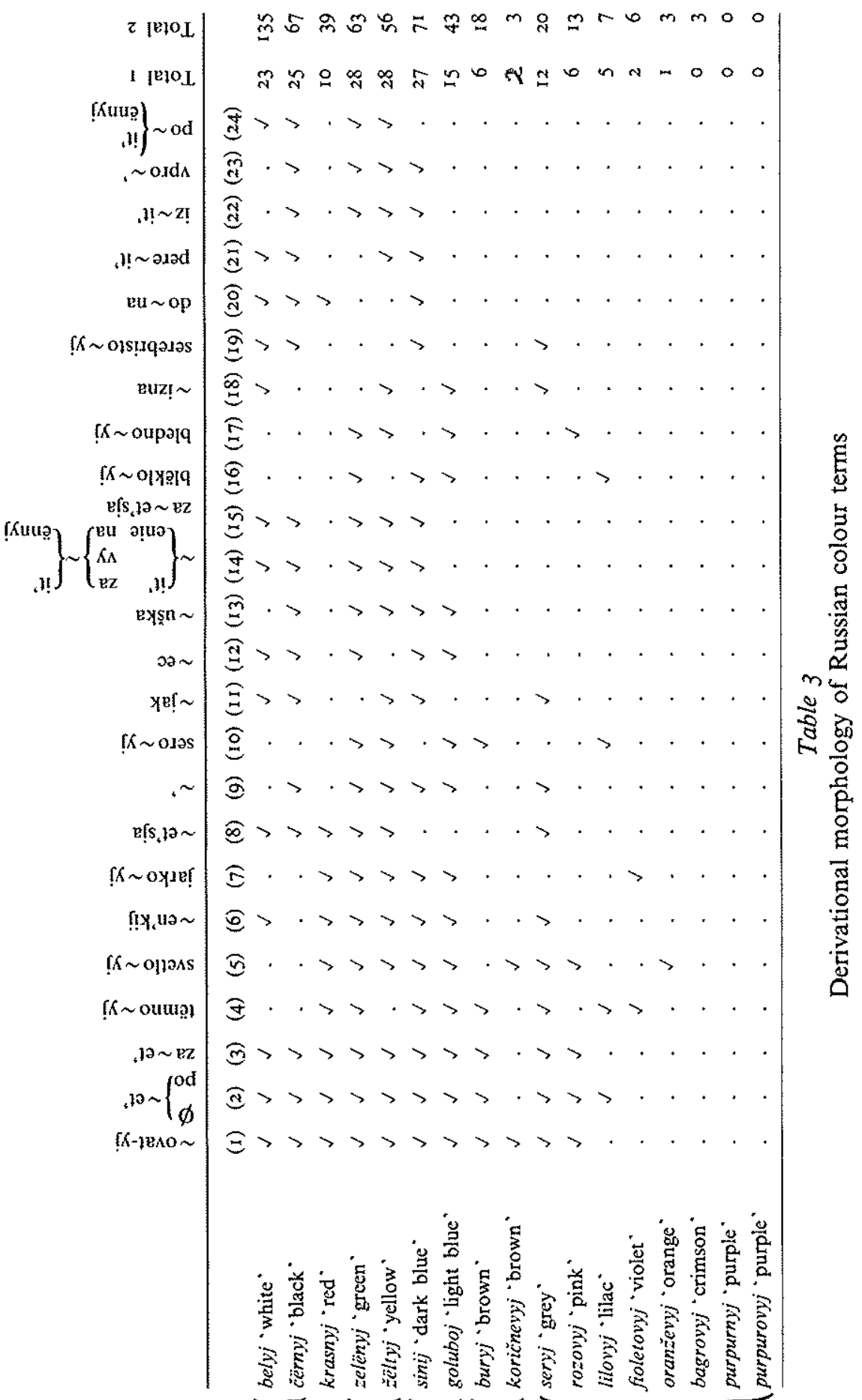




\section{Notes to Table 3}

The typical uses of the affixes in columns $(1 \cdots 24)$ can be briefly characterized as follows:

(1) ovat-: adjectival qualifier 'ish".

(2) $\sim e t$ ': formative of intransitive verbs, 'to become COLOUR' (po-perfective aspect).

(3) $z a \sim e t$ ': as 2 , but inceptive, 'to begin to become COLOUR'.

(4) tëmno yj: prefixed modifier, 'dark COLOUR'.

(5) svello $\sim y j$ : prefixed modifier, 'light COLOUR'.

(6) $\sim e n ' k i j$ : diminutive suffix.

(7) jarko $\sim y$ : prefixed modifier, 'bright COLOUR'.

(8) er'sja: formative of instransitive verbs, 'to show up COLOUR'.

(9) ': formative of abstract nouns, e.g. zelen' 'greenery'.

(10) sero $\sim y j$ : prefixed modifier, 'greyish-COLOUR'.

(i I) $\sim$ jak: formative of concrete nouns, e.g. beljak 'white hare'.

(12) $\sim e c$ : formative of concrete nouns, e.g. cernec 'monk'.

(13) uskka: formative of diminutive nouns, e.g. čermiska 'nutmeg'.

(14) (a) $\sim i t$ ': formative of transitive verbs, e.g. belit' 'to whiten'. (b)

enie: nominalizing suffix, e.g. belenie 'bleaching'. (c) $z a \sim i t$ ':

formative of transitive verbs (perfective inceptive), e.g. zabelit'

'to start whitening'. (d) na it': perlective of (14a), e.g. nabelit',

'to whiten'. (e) $y y \sim i t$ ': perfective of (14a), e.g. yybelit' 'to

bleach'.

(I5) za et'sja: formative of intransitive verbs (perfective),

e.g. zabelet'sja 'to show up white'.

(16) blëklo yj: prefixed modifier, 'faded COLOUR'.

(17) bledno yj: prefixed modifier, 'pale COLOUR'.

(18) izna: formative of abstract nouns, 'COLOUR-ness'.

(19) serebristo $\sim y$ : prefixed modifier, 'silvery COLOUR'.

(20) do a: adverbial formative, 'to the point of being COLOUR'.

(2I) pere $\sim i t$ ': formative of transitive verbs (perfective), e.g. perebelit'

'to whitewash again'.

(22) $i z \sim i t^{\text {' }}$ : formative of transitive verbs (perfective), 'to render thoroughly COLOUR'.

(23) vpro ': adverbial derivative of (9), e.g. vykrasit' vproželt' 'to paint with a yellowish tinge'.

(24) (a) po $i i^{\prime}$ : perfective of (14a), 'to make COLOUR'.

(b) po ennyj: participial formative, 'made COLOUR'.

example, shows which colour roots are found in conjunction with the suffix -ovat "-ish". The root bel of the adjective $b e l-y j$ 'white' has a tick against it in the first column, which indicates the existence of the form bel-ovat-yj 'whitish'. The tilde shows that it is simply the root bel 'white' that combines with the suffix -ovat-and its adjectival ending $-y j$. A tilde has been used 
throughout the table to show that a colour root should be inserted. Moving down the column we come to cerrn-yj 'black'; this too can be conjoined with the suffix -ovat-. The tilde once again shows that the root čern gains the suffix -ovat- to become cernovatyj 'blackish'. The same is true for the next three items in the colour list: krasn-yj 'red', zelën-yj 'green' and žell-yj 'yellow', which have the derived forms krasnovatyj 'reddish', zelenovatyj 'greenish' and želtovatyj 'yellowish'.

The next item, sin- $y j$ 'dark blue', deserves consideration; it, too, takes the suffix in question. Its adjectival ending, which in this case is not $-y j$ but $-i j$, indicates that the final $n$ of the root $\sin$ is the palatalized consonant $/ n^{3} /$. A palatalized consonant is necessarily followed by the adjectival ending $-i j$ in Russian, while a hard (unpalatalized) consonant generates the ending $-y j$ (or $-o j$ if stressed). After roots ending in a palatalized consonant, the suffix takes the form -evat, to give sinevatyj 'bluish'. The few automatic alternations of this type are not spelled out in the table. The following items, golub-oj 'light blue' (end-stressed, as explained above, hence the $-o j$ ), bur-yj 'brown', and $s e r-y j$ 'grey' also combine with -ovat- to give golub-ovat-yj 'light bluish', bur$o v a t-y j$ ' brownish' and ser-ovat-yj 'greyish'. Stems ending in -ov or -ev delete one occurrence of $-o v$ when combined with -ovat-. One therefore finds koričnevat-yj (not *koričnev-evat-yj) and roz-ovat-yj (not *rozov-ovat-yj), and similarly, lilovatyj and oranževatyj. (For a discussion of the phenomenon of the non-repetition of morphs see Menn \& McWhinney (I984) and references there.)

The bottom six items are not ticked in the first column, which shows that they were not entered with the suffix -ovat-in the original source. They are lilovyj 'lilac', foletovyj 'violet', oranževyj 'orange', bagrovyj 'crimson' and purpurnyj 'purple'. In other words, the forms *lilovatyj 'lilac-ish', *foletovatyj 'violetish', *oranževatyj 'orangish', *bagrovatyj 'crimsonish', *purpurnovatyj and *purpurovatyj 'purplish' were not recorded in the source on which Worth et al. is based. Indeed, the status of the English translation equivalents we have given is also dubious.

The second column, of course, functions in a similar way. It differs in that it represents the grouping together of two combinations of affixes with identical distribution. Each such combination includes the verbal suffix $-e t$ ' (where the apostrophe represents a soft sign in Russian orthography, a sign of palatalization). Each form is preceded by the prefix po- (which adds the nuance of completed action) or zero, which is represented in the table by $\emptyset$. Thus for the root bel 'white', there are two possibilities: bel-et' 'to become white', and po-bel-ef' 'to become white' (completed). The ticks in the second column show that analogous forms exist for all basic colour roots down as far as bur-yj 'brown'. But no such form was recorded for koričnev$y j$ 'brown'. The only roots below bur-yj in Berlin \& Kay's scale which were found with these two combinations of affixes are $s e r-y j$ 'grey', rozoy-yj 'pink' and lilov-yj 'purple'. 
The final two columns show, for a given colour root: (I) The total number of items in the present table (taking into account economies as explained above); (2) The total number of items in the study by Worth et al. This second figure includes items not entered in the table due to an insufficiency of analogous items based on other colour roots (i.e. less than four such items). ${ }^{9}$

Contrary to Dixon's (1982:23-24) hypothesis, it is clear from the present table that there ARE cases of words lower on Berlin \& Kay's scale having morphological possibilities not enjoyed by words higher up. However, it would be true to say that those higher up typically have greater derivational possibilities. This tendency can be observed by examining the arrangement of ticks on the table. It is also reffected in the columns showing totals. Nonetheless, there are some interesting discrepancies that merit discussion. Bel-yj 'white' and čern- $y j$ 'black' have more derivatives than almost any other root. Their 'early omissions', in columns (4), (5), (7), (I6), (I7) and perhaps (IO), can be explained semantically. It would make no sense, for example, to talk of *svetlo-bel-yj 'light white' (column 5). However, it is surprising that bel-yj should have so many more derivatives than $\check{c} \ddot{e r n} n-y j .^{10}$ Although krasn- $y j$ ' red' has surprisingly few derivatives, we feel that there is an interesting explanation for this, which will be presented in Section 6.2 below. Zelën-yj' 'green' and žëlt-yj'yellow' each have as many derivatives as one might expect, given their positions on Berlin \& Kay's scale. Sin-ij 'dark blue' and golub-oj 'light-blue' both correspond to Berlin \& Kay's blue. One might therefore imagine that their totals could be merged to form, statistically speaking, a single item. But this is not the case. In fact each has more derivatives than any root lower on the scale. And simijalone, quite apart from having more derivatives than goluboj, has more than any root on the table with the exception of černyj.

As stated above, koričnevyj is the Russian colour term given by Berlin \& Kay for brown. Yet a different word for brown - buryj-is attributed more derivative forms by Worth et al. An important factor here is that koričnevyj is itself a derived form, and possibilities for combining derivational affixes are limited - Vasmer $(1953: 1,627)$ gives koričnevyj as being derived from korica 'cinnamon', itself a derivative of kora 'bark'." Note that since the form koričnevyj has been derived by suffixation, the addition of the prepositive compounding form svetlo- 'light' poses no problem. Hence the form svetlo-

[9] Thus for example bagrow-yj 'purple ' has three derivatives, but none of them is included in the more common ones listed in the table.

[10] Attempts to account for this discrepancy through etymology were inconclusive. Sanskrit cognates have been proposed for both words: kršna for čëmyj (Cyganenko, 1970: 536) and bhalam for belyj (Vasmer, 1953: I, 73). Vasmer also gives cognates for belyj in olher IndoEuropean languages.

[11] Cyganenko (1970:217) gives koričnev-yj as being derived from korič-nyj pertaining to cinnamon ', itself derived, of course, from korica 'cinnamon'. Vasmer (1953) traces the root of buryj back to the twellth century. 
koričnevyj (cited in Worth et al., due to a typographical error, as "sveglokoričnevyj'). In addition to this form, Tixonov (1985) gives koričnev-en'k-ij 'brown' (diminutive) and tëmno-koričnev-yj 'dark brown'. These two forms do not, of course, appear in the present table as it is based entirely on the findings of Worth et al. Ser-yj 'grey' also stands out as an item with a number of derivations disproportionate to its position on Berlin \& Kay's scale. Indeed, Berlin \& Kay (1969:45) note that the premature appearance of grey in Hopi, Samal and Papago may suggest that this colour is a 'wild card', capable of appearing at various stages of the evolutionary sequence. Kay (1975:26I) supports this view with new data and Kay \& McDaniel (1978:640n.) suggest that grey may occur at a stage where there are only four basic colour terms, or 'possibly even earlier'. In the light of this, the position of grey on the present table is particularly striking: it lies (in terms of total number of morphological possibilities) immediately above brown. The positions of the remaining items on the table deserve no particular mention.

\section{FREQUENCY DATA}

The second way in which the Berlin \& Kay hierarchy might be reflected in a language which has a full or nearly full set of colour terms is in the relative frequency of their use. We predict that the higher a term is on the hierarchy, the more frequently it will occur. We shall first test this prediction against a range of different sources of data, and then in the next section compare the results with those gained from the morphological investigation. Unknown to us when we carried out this research, frequency counts have been used by Hays et al. (1972); they found a high correlation between frequency rank and position on the Berlin \& Kay hierarchy in eight languages including Russian. Our work goes beyond theirs in two ways. First, they used only one source for Russian (Štejnfel'dt), while we use a variety of sources, several of which give more detailed data. Secondly, and more significantly, Hays et al. take the inventory of basic colour terms as given, and investigate ranking within this list. We use frequency also as a diagnostic to help establish basicness where the status of certain colour terms is not clear.

The major statistical source used is the frequency dictionary edited by Zasorina (1977). This was compiled from a corpus of one million words ( $I, 056,382$ in fact) of twentieth-century Russian. The corpus comprised four approximately equal sets of texts as follows: (I) journalism (newspapers and magazines); (II) drama (intended to reflect conversational Russian); (III) nonfiction (especially political texts); (Iv) literature (prose, no poetry). In Table 4 we first give the total occurrences of the particular colour term, followed by its occurrences in each of the four genres (I-IV just listed). For ease of reference the colour terms are listed in the same order as in Table 3. As a check against a distorted picture being produced by idiosyncratic use in 
COLOUR TERMS IN RUSSIAN

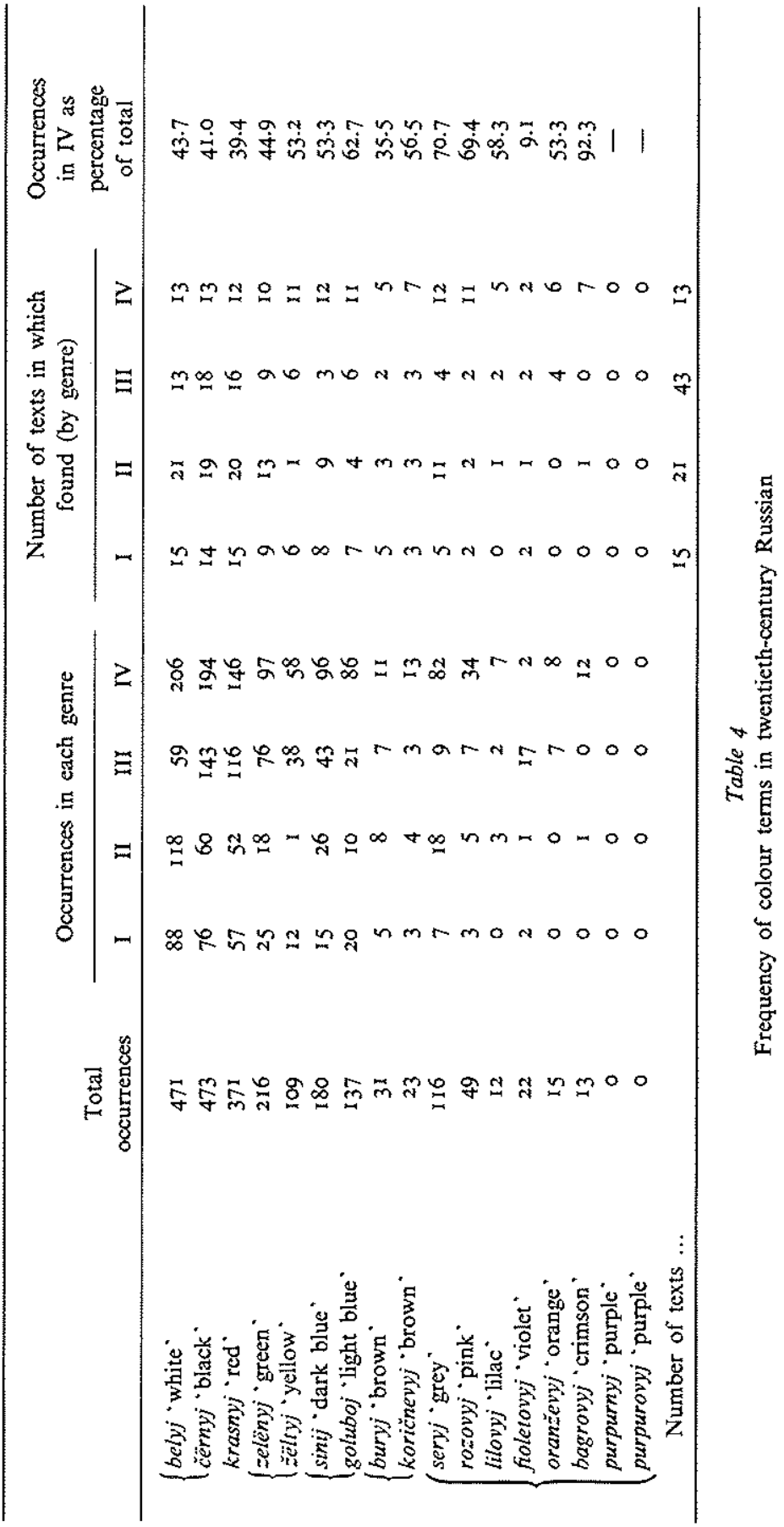


particular texts, we also list the number of texts in each genre in which the colour term occurred. Finally we have calculated the occurrences in literary texts (IV) as a percentage of the total.

Table 4 is to be read as follows. Belyj 'white' in its various inflected forms (but not including derivatives excepting the synthetic comparative and superlative) was found in the corpus $47 \mathrm{r}$ times. Of these, 88 occurrences were in journalistic texts, 118 in plays, 59 in non-fiction, 206 in literature. It occurred in all $\mathrm{I} 5$ of the journalistic texts and all $2 \mathrm{I}$ of the plays excerpted, in only 13 of the 43 non-fictional texts and in all of the 13 literary texts. Its 206 occurrences in literary texts make up 43.7 per cent of its total occurrences. The question of distribution by genre is one to which we return below.

Let us now consider the colour terms in order. Our main focus will be on the total occurrences in the first column. Belyj 'white' and černyj 'black' have the highest numbers of occurrences. They also have very similar totals (47I and 473). However, this similarity conceals rather different distributions: belyj was found almost twice as often as čermyj in plays (column II), which were included to reflect spoken language, but are likely to do so only to a limited degree. On the other hand cërmyj occurred more than twice as frequently as belyj in non-fictional texts. Krasnyj 'red' is as we might expect: less common than belyj or černyj but more common than any other colour. (We discuss it more fully in Section 6.2.) Zelënyj 'green' is also in its expected place, according to the Berlin \& Kay hierarchy (the brackets on the left again indicate these positions). However, the figure for žëltyj is surprisingly low - lower than those of sinij 'dark blue', goluboj 'light blue' and even seryj 'grey'. Žëltyj is less common in all genres than expected; note in particular the single occurrence in plays, which suggests that it may be rare in the spoken language. ${ }^{12}$ This discrepancy with zëltyj is particularly surprising since the yellow-green area is that to which people with normal colour vision are most sensitive (Rabkin, 1962:24). There is, however, a remarkable correlation with certain other languages. Hays ef al. (1972: I I12) investigated English, Castilian Spanish, French, German, Russian, Romanian, Japanese and Hebrew. In the first five of these languages (although they do not draw attention to this fact), yellow ranks below blue; in two out of three English samples it ranks below brown. We have no explanation for this mystery.

Apart from the fact that they are more common than žëltyj, sinij 'dark blue' and goluboj 'light blue' have frequencies in the range expected. Note too that each one independently is sufficiently frequent to occupy the 'blue slot' on the hierarchy; there is no question of needing to combine their frequencies to maintain the hypothesis that frequencies will follow the

[12] Wade (1985) examines new metaphors based on colour terms in Russian and notes that belyj, goluboj, zelënyj, krasnyj and č̈rnyj are particularly common. The absence of zëltyj is noteworthy, as is that of simij. 
hierarchy. This fact again supports the claim that both sinij and goluboj are basic colour terms. There are two differences between them: the obvious one is that simij is somewhat more frequent; the second is that goluboj appears to be a more literary word, since 62.7 per cent of its occurrences were found in literary texts as oppposed to 53.3 per cent for sinij. The words for brown, buryj and koričnevyj, are again problematic. Though we claim that koričnevyj is the basic term, it occurs less frequently than does buryj. We suspect that this may result from the use of buryj in certain fixed expressions (like buryj ugol' 'brown coal'); when we discuss other frequency counts we shall see that the positions are reversed. Nevertheless, even taken together, the terms for brown are less frequent than that for grey and even than that for pink. Again this is a problem to which we will return. The high figure for seryj 'grey' is something of a surprise. However, as pointed out in Section 4, the position of grey has been revised, and it may occur higher up the hierarchy than was believed previously. Our data help to confirm this revised view. It is also surprising, perhaps, that seryj 'grey' is so common in literary texts.

The remaining colours all have frequencies below those higher on the hierarchy (apart from rozovyj 'pink' being above buryj and koricheyyj, as mentioned). Fioletovyj 'violet' stands out as occurring much more frequently in non-fictional texts (III) than in any other genre; it is clearly a somewhat technical word. Bagrovyj 'crimson', on the other hand, is a markedly literary word. Finally purpurnyj 'purple' did not occur once in a corpus of over one million words, a corpus in which 39,268 individual words were represented. This makes the claim that it is a basic colour term appear dubious. Equally purpurovyj was not found and so is unlikely to be a basic colour term.

Let us now look at the last column. Recall that the four genres were represented approximately equally in the corpus; it is clear that the majority of colour terms are found considerably more frequently in literary texts than in other genres, since the percentage is almost always well in excess of 25 per cent. There is an interesting tendency for the colour terms lower on the hierarchy to be more literary than those higher up: thus želt $y j$ is the first with more than 50 per cent of its occurrences being found in literary texts; below $z \ddot{z} l t y j$, only buryj and fioletovyj have less than 50 per cent of their occurrences in literary texts. The question of distribution by genre deserves further investigation. Table 5 gives the total occurrences by genre of the colour terms investigated (the totals of columns $2-5$ in Table 2), both as raw figures and as percentages.

\begin{tabular}{lccccr}
\hline Genre & I & II & III & IV & Total \\
\hline Occurrences & 313 & 325 & 548 & 1052 & 2238 \\
Occurrences as percentage of total & 14.0 & 14.5 & 24.5 & 47.0 & 100 \\
\hline
\end{tabular}


It is clear, and not altogether surprising, that colour terms occur much more frequently in literary texts than in any other genre. They are also more frequent in non-fictional texts ( 24.5 per cent) than in either of the other two genres. Zasorina is the most important statistical source, and we carry forward the total occurrences in Zasorina's corpus to Table 6. We also present there data from other sources which are valuable for comparative purposes. First there is the Pushkin Dictionary (Vinogradov et al, 1956-61), which is a concordance of almost all of the work, both prose and poetry, of Pushkin (1799-1837). Each entry in the Pushkin Dictionary gives the number of occurrences; for the more common words there may also be figures for use in secondary meanings and set expressions; following our general approach we accept the analysis of the editors and give two figures in Table 6: first the total for each colour term and then the figure with secondary meanings and set expressions deducted. ${ }^{13}$ Next we give data derived from the Mandelshtam Concordance (Koubourlis, 1974). This concordance is based on the complete poetry of Mandelshtam (I891-I938), comprising almost 9000 lines, around 4I,000 words of text, including approximately 16,000 different words. The Concordance lists derivatives together with the root so that we could not simply total the figures given; however, it is relatively straightforward to count up the various inflexional forms of the colour terms while excluding derived forms (for both Pushkin and Mandelshtam we were able to exclude synthetic comparatives and superlatives, which was not possible elsewhere).

Štejnfel'dt (1963) is a more general frequency dictionary, based on a corpus of 350 texts totalling 400,000 words. The corpus consisted of four equal parts: children's literature, adult literature (prose and plays), radio broadcasts for the young, and newspaper texts. Most of the material is from the period 1956-9. Though 24,224 different words (excluding proper names) were found, data are given only on the most frequent 2500 (the dictionary was designed for pedagogical purposes). This is an important point; it means that a word not included in the dictionary may have occurred in the corpus (which is not the case for the Pushkin Dictionary, the Mandelshtam Concordance and Zasorina). We indicate this in Table 6 by means of a dash; this indicates a lack of specific information (which in the case of the Stejnfel'dt dictionary means that a word was not one of the most common 2500 , the cut-off point being determined by a combination of absolute frequency and number of occurrences in different texts, 1963:31-32).

Our final source is a frequency dictionary of conversational Russian (Abakumova et al., 1968); it is valuable as it provides data on genuine conversational Russian (rather than indirectly through the use of plays), but it was compiled in an unusual way. Conversations were recorded from I 964

[13] Esser (1979) includes information of colour expression in $W$ ar and peace but does not separate the basic colour terms from others. 


\section{COLOUR TERMS IN RUSSIAN}

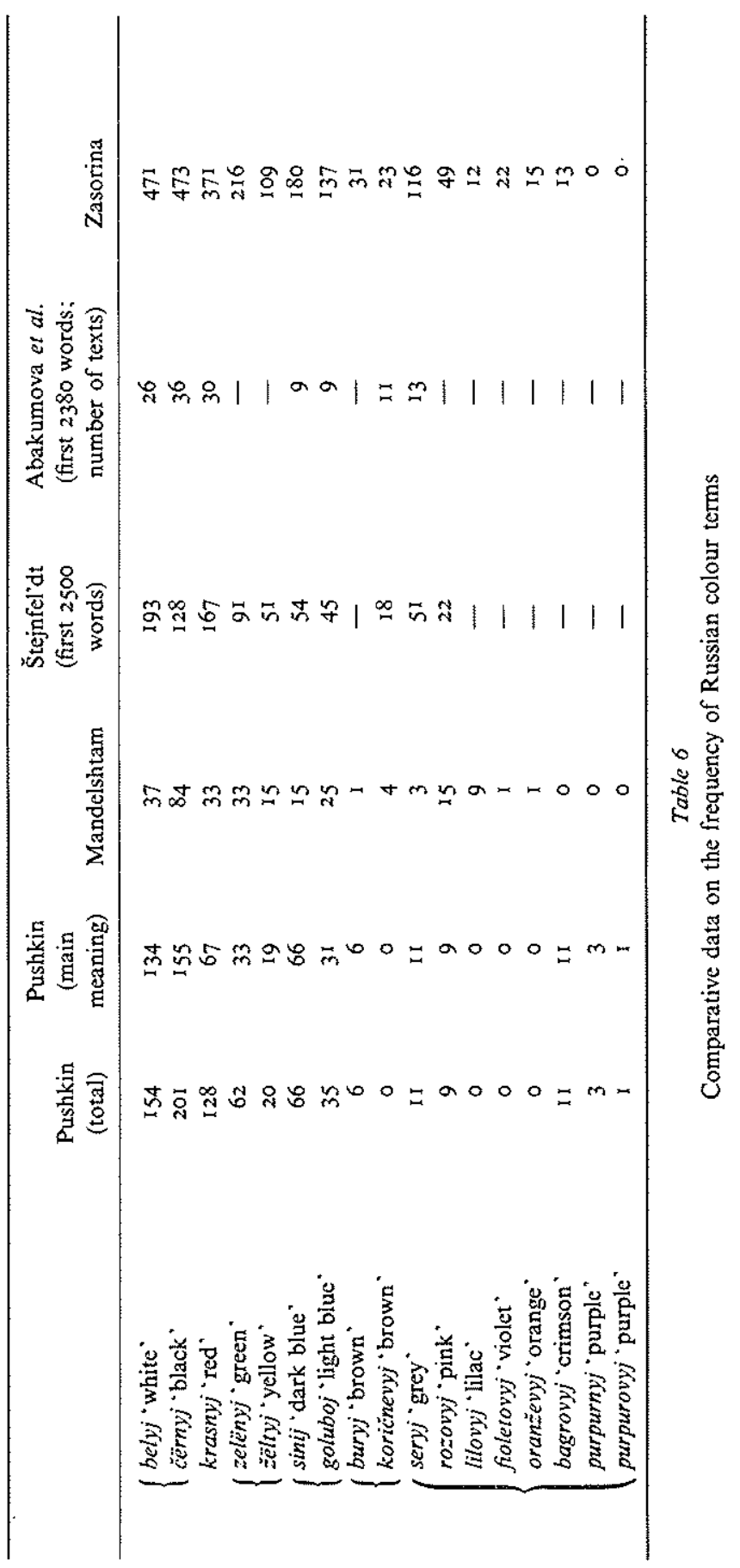


to 1966 , involving a large number of different speakers; the conversations totalled 400,000 word uses (14,800 different words). Then individual words were assigned a total according to the number of segments in which they appeared. Only those which were found in 8 or more of the segments were included in the dictionary, a total of 2380 words. Thus the figures in the relevant column in Table 6 are helpful, but cannot be directly compared with ordinary frequency figures (they could, however, be compared with the seventh column of Table 4). The last column in Table 6 simply repeats the totals from Zasorina.

From the variety of sources in Table 6 we see that belyj 'white' and črmyj 'black' are generally the most frequently occurring of the colour terms. However, there are more examples of krasnyj 'red' than of černyj in the Stejnfel'dt corpus, and krasnyi was found in more texts of the spoken corpus than was belyj. The data on krasnyj from the Pushkin Dictionary are also of interest; the large difference between the total occurrences and those with the colour meaning show that at the beginning of the last century the earlier meaning 'beautiful, special' was still common.

In most cases, sinij 'dark blue' and goluboj 'light blue' are attested more than sufficiently to justify their places individually on the hierarchy; in addition, it is always the case that at least one of them has a higher frequency than that of zeellyj 'yellow', and often the break in the pattern is more marked than that. Bear in mind that '- - indicates that the word was not sufficiently frequent to be included in the dictionary, not that it did not appear in the corpus. In fact sinij and goluboj only just merited inclusion in the conversational Russian dictionary (Abakumova et al., I968) as each was found in 9 texts: the qualifying number was 8 . Thus the difference between these two and zelënyj 'green' and želtyj 'yellow' may not have been great: there is no way of telling.

The position of brown is particularly interesting. In the nineteenth-century corpus (Pushkin) only buryj is found, while in all the twentieth-century corpora koričnevyj is well attested, being the more frequent of the two in all but Zasorina. The evidence suggests that the newer, derived form koričnevyj is taking over from the older, non-derived buryj. This situation is similar to that found in French by Forbes (1979), where marron is beginning to supplant brun. Though our data are less complete than those of Forbes, since there is not the same range of word-counts available for Russian, it would appear that the situation is changing more rapidly in Russian than in French. ${ }^{14}$

Of the remaining colours, seryj 'grey' and rozovyj 'pink' are well

[14] It is interesting to note that in Zollinger's 1976 experiment for eliciting colour terms in five different languages (not including Russian), $4^{8}$ per cent of French informants considered brun to be 'necessary' in a colour-term lexicon, while the other $\$ 2$ per cent considered it 'desirable'. Marron, on the other hand, did not even achieve the total score of 10 per cent which would have qualified it to feature in Zollinger's table. 
represented. The rest present a confused picture. Fioletovyj 'violet' occurs in Mandelshtam, suggesting it is not exclusively a technical term; the appearance of bagrovyj 'crimson' only in the Pushkin Dictionary of the new sources confirms the previous evidence that it is a literary word; purpurnyj and purpurovyj 'purple' at last make an appearance, but only in literary texts of the last century.

The data on the poetry of Mandelshtam are interesting since they are the most restricted (to one writer and one genre) and therefore potentially the most idiosyncratic. Indeed čërnyj occurs more than twice as frequently as belyj. Unusually too, goluboj is more frequent than sinij, which tends to confirm the point made in the discussion of Table 4 , that goluboj is more literary than is sinij. Note too that seryj is relatively rare, being less common than rozovyj and lilovyj. But the main point about this corpus is the overall high frequency of colour terms as a group; this can be seen by comparing the occurrences of various colour terms in Mandelshtam with those of the Štejnfel'dt corpus, which is approximately ten times the size of the Mandelshtam corpus. ${ }^{15}$

Given that the sources we have used were compiled by different methods, they cannot be combined in any direct way. We therefore combined the results using rank ordering. The results are presented in Table 7 . Within each corpus (and we treated the four corpora of Zasorina separately for this purpose) the colour terms were ranked according to frequency. One point was scored for the most frequent, two for the second, and so on; two terms third equal score 3.5 , three terms third equal each score 4 . Then we calculated the average rank; clearly the lower the score, the higher the overall frequency. On the basis of the average rank, the colour terms are given an overall position in the last column.

When we consider the data in Table 7, it is worth recalling the 'null hypothesis', namely that the Berlin \& Kay hierarchy would make no prediction about a language that had already acquired a full set of colour terms. In fact we see a surprisingly high degree of correlation between the Berlin \& Kay order and the overall position in the rank table. This is particularly true for the top part of the table; note too the consistency of the rankings higher in the table: $\check{c} \ddot{m} m y j$, for example, is nowhere lower than third. Belyj 'white' and čermyj 'black' are indeed the two most frequent colour terms, and there is little difference in their average ranks. Krasnyj 'red' has a markedly lower average rank than these two terms, but a substantially higher average rank than any other remaining colour term. Zelënyj 'green'

[15] This adds support to a very interesting finding of Moskovič (1969: 138-144), who compared the frequency of usage of colour terms by four authors, who had each written two texts on similar topics, one in poetry and one in prose. Colour terms occurred on average four times more frequently in the poetry. Moskovič states (1969: 142) that certain colour terms, including buryj, koričnevyj and oranzevyj, were not found in his corpus of poetry; all of them are found in the larger corpus of Mandelshtam's work. 
GREVILLE CORBETT AND GERRY MORGAN

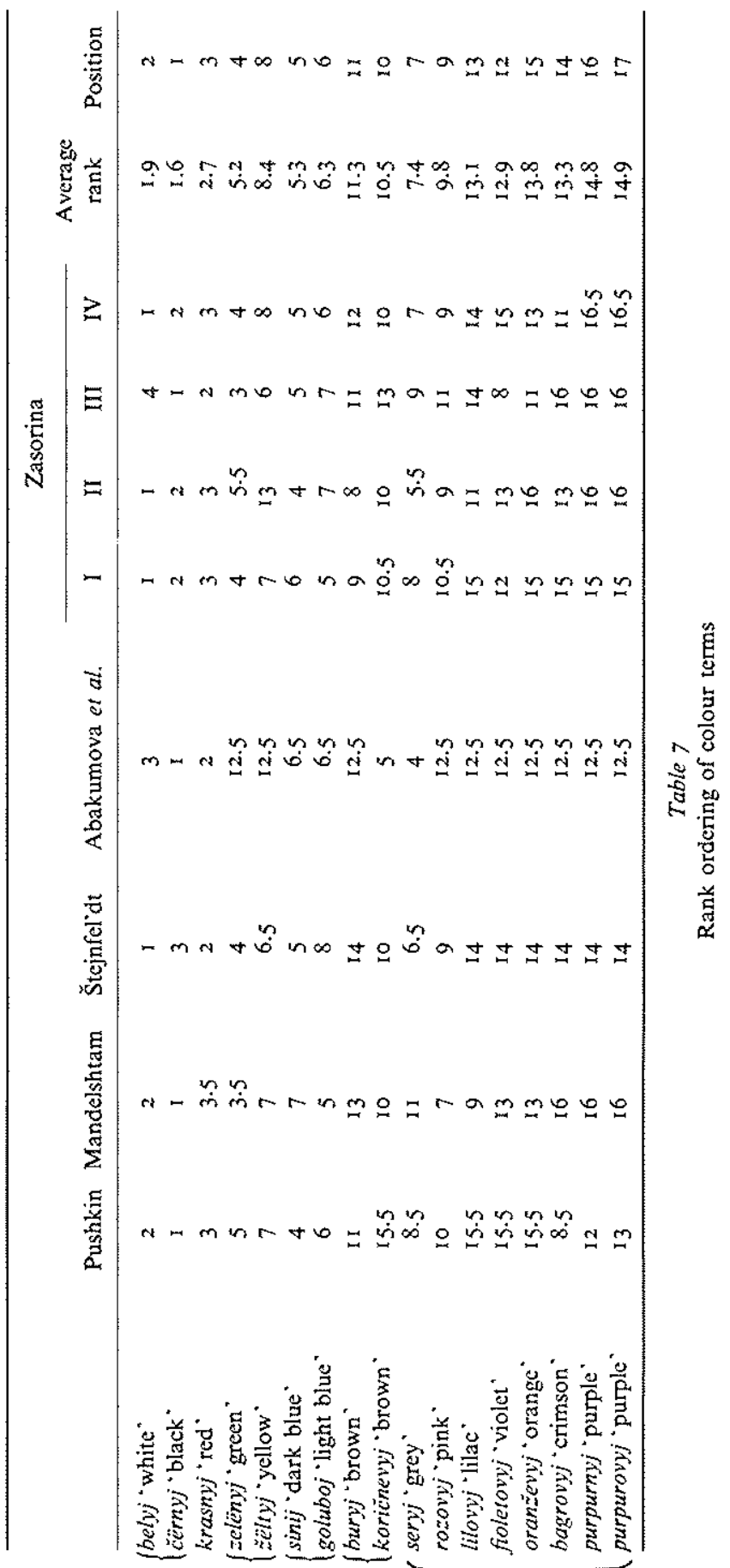


has an average rank corresponding to its position on the Berlin \& Kay hierarchy, but želtyj 'yellow' is, as we have already noted, less frequent than expected, its average rank placing it below seryj 'grey'. Apart from that, the average ranks continue in accord with the hierarchy; sinij 'dark blue' and goluboj 'light blue' each have an average rank which would place them at the appropriate point on the hierarchy for blue. There is no sense in which they combine to occupy the blue slot, they are established there independently. The terms for brown, on the other hand, are 'out of order'; their average rank puts them below seryj 'grey'; as already discussed, grey may be seen as a wild card and so this does not present a problem. However, they also come below rozovyj 'pink'. This latter is clearly much better established than any of the remaining lower groups of colours. Most of the remainder are bunched with average ranks of $\mathrm{I} 2.9-\mathrm{I} 3.8$; these data would not give clear indications as to which should be recognized as the basic terms. However, purpurnyj and purpurovy 'purple' are firmly in bottom position, which suggests that they are not among the basic terms.

In view of the contrast between the two terms for blue and the two terms for brown, we recalculated the rank ordering treating koricnevyj 'brown' and

\begin{tabular}{|c|c|c|c|c|c|}
\hline & $\begin{array}{c}\text { Overall } \\
\text { rank }\end{array}$ & Position & & $\begin{array}{c}\text { Overall } \\
\text { rank }\end{array}$ & Position \\
\hline (belyj 'white' & I.9 & 2 & seryj 'grey' & 7.7 & 7 \\
\hline (cêrmyj 'black' & 1.6 & 1 & rozovyj 'pink' & 9.7 & 10 \\
\hline krasnyj 'red' & 2.7 & 3 & liloyyj 'lilac' & 12.4 & 12 \\
\hline felënyj 'green' & 5.1 & 4 & foletovyj 'violet' & 12.3 & 11 \\
\hline \{zëltyj 'yellow' & 8.2 & 8 & oranzevyj 'orange' & 13.2 & 14 \\
\hline sinij 'dark blue' & $5 \cdot 3$ & 5 & bagrovyj 'crimson' & 12.6 & 13 \\
\hline lgoluboj 'light blue' & 6.4 & 6 & purpurnyj 'purple' & 14 & 15 \\
\hline \{buryj 'brown' AND & & & purpurovyj 'purple' & I4.I & 16 \\
\hline ( koricnewyj 'brown' & 8.8 & 9 & & & \\
\hline
\end{tabular}

Table 8

Rank ordering combining terms for 'brown'

buryj 'brown' together as one term, adding their occurrences together. For simplicity we give only the average rank and position in Table 8 ; the interested reader can derive the full rank orderings from previous tables.

Once the terms for 'brown' are treated as one, a remarkably regular picture emerges. The one remaining irregularity concerns žëltyj 'yellow'; we have no explanation as to why this one colour term is not in the position corresponding to its place on the Berlin \& Kay hierarchy. Grey is known to be a wild card, and comes before rather than after brown. When the terms for brown are combined they fit in their appropriate place. We suggest that koričnevyj is in process of establishing itself as the single term for brown. This 
situation is clearly different from that for blue, where both terms independently are sufficiently frequent to justify their position. The frequency data mirror closely the Berlin \& Kay hierarchy and also highlight interesting facts about the language under investigation, confirming the general belief about the terms for blue, suggesting a solution to the brown problem, and isolating an unsuspected problem with yellow. We conclude that they are a powerful tool for investigating systems of colour terms.

\section{REVIEW OF FINDINGS}

Having produced a wealth of data on Russian colour terms, we must now assess their importance both for the body of theory based on Berlin \& Kay's work (Sections 6.1 and 6.2) and for the description of the colour system of Russian (Section 6.3).

\section{I. Criteria for determining basic colour terms}

We have seen that even in a language as well studied as Russian it is not at all straightforward to establish the inventory of basic colour terms. It is not clear which, if any, of the five terms examined should be considered a basic term corresponding to purple. There were also problems with koričnevyj and buryj, both meaning 'brown'. We therefore review the criteria proposed by Berlin \& Kay $(1969: 4-6)$ in the light of the evidence we have presented. Berlin \& Kay propose four main characteristics and four subsidiary ones. They state, however, that 'the expression basic color term does not have a unique operational definition' (1969:6). Table 9 shows in summary form the results of applying the criteria to the terms we have analysed; there follow comments on the various criteria.

The first of Berlin \& Kay's criteria is that a basic term must be 'monolexemic', that is, 'its meaning is not predictable from the meaning of its parts' (1969: 6). As the table shows, all the chosen Russian terms satisfy this criterion. It might be argued that rozovyj ' pink' is clearly related to roza 'rose', but one could not predict that rozovyj means the colour of a rose which is pink. As all the terms in the present table satisfy this first criterion, Berlin \& Kay's eighth criterion need not be considered. It serves only as a further check in the case of terms that are doubtful on the first criterion. While all the terms analysed meet the first criterion, it should be pointed out that there are many colour terms which are excluded from consideration by it, and which are therefore not included in the table. These include, for example, derived forms in -ovat-, such as zelenovatyj 'greenish'.

The second criterion is that the significance of a colour term "is not included in that of any other colour term' (I969:6). Of the terms analysed, the status of buryj 'brown' is not fully clear. (For example, some English-Russian dictionaries translate brown as koričnevyj, while others give 
COLOUR TERMS IN RUSSIAN

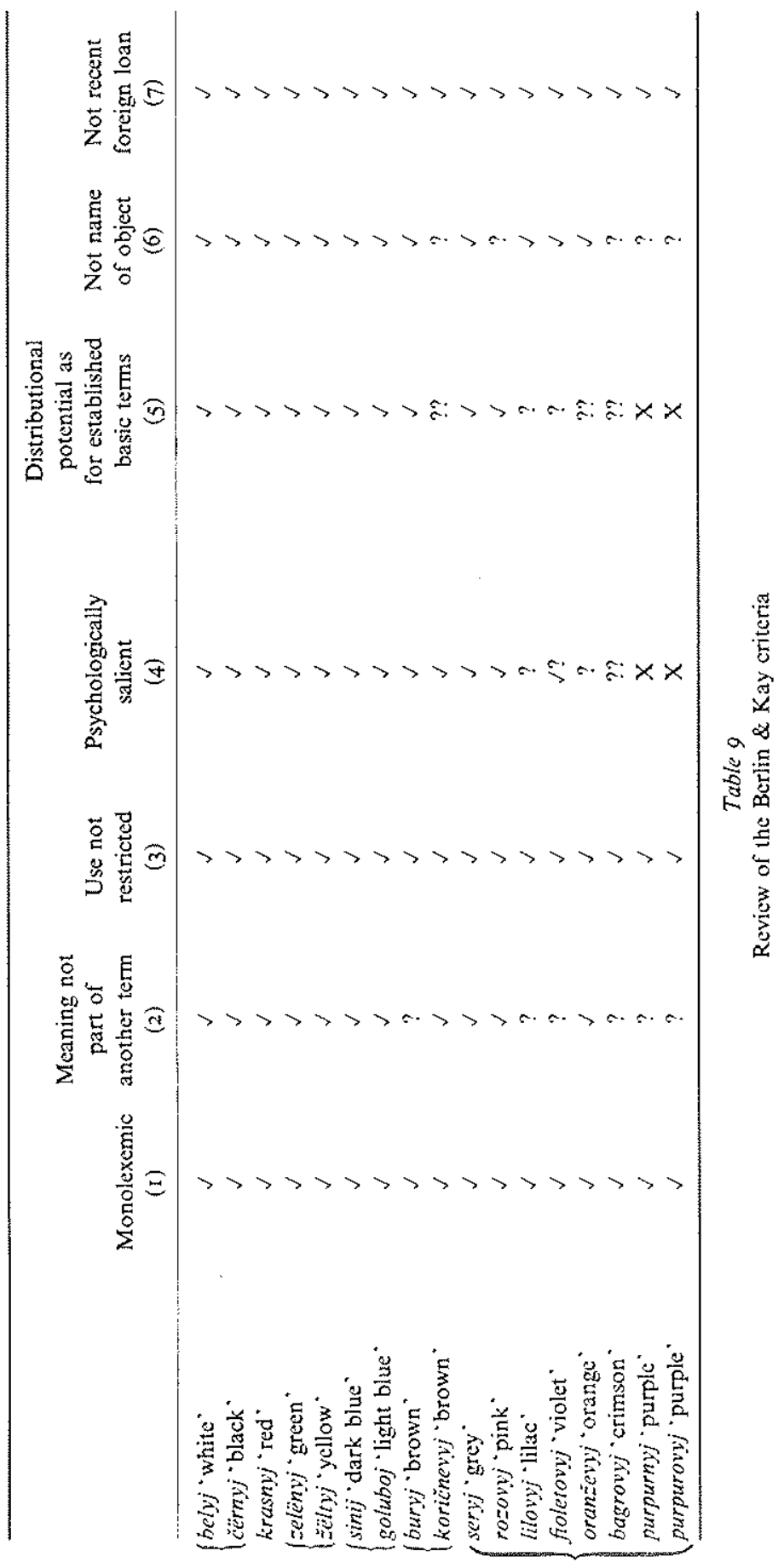


both koričnevyj and buryj. This suggests that koričnevyj is a stronger contender for basic-term status.) A more complex situation prevails in the field of purple, where the relative ranges of five Russian terms require elucidation. The third criterion is that the term 'must not be restricted to a narrow class of objects' (1969: 6). As column (3) shows, none of the terms investigated fails here, but it should be pointed out that purpurnyj 'purple' and purpurovyj 'purple' are largely reserved for natural phenomena (Evgen'eva, I971: 1, 35).

The last of the four main characteristics of a basic colour term is as follows:

It must be psychologically salient for all informants. Indices of psychological salience include, among others, (I) a tendency to occur at the beginning of elicited lists of color terms, (2) stability of reference across informants and across occasions of use, and (3) occurrence in the ideolects [sic] of all informants (Berlin \& Kay, I969:6).

This is a criterion to which our data are particularly relevant. Items which are only rarely used cannot be considered salient. And items restricted to certain genres clearly are not found in the idiolect of all speakers. Looking back to the frequency data presented in Table 4 , we count items which occurred in all four genres of Zasorina's corpus as meeting this criterion. However, the predominantly non-fictional use of foletovyj 'violet' ( 17 examples out of 22) led us to question whether it is truly psychologically salient, hence '?'. Terms which occur in only two genres have an even weaker claim to being salient; these are marked with a question mark. Bagrovyj 'crimson' is still less clear, since $\mathrm{I} 2$ out of the 13 occurrences are in literary texts; it is therefore marked '??'. The remaining terms did not occur at all in the corpus and are marked ' $\mathrm{X}$ '.

The first of the subsidiary criteria is that:

The doubtful form should have the same distributional potential as the previously established basic terms (Berlin \& Kay, 1969:6).

The examples given by Berlin \& Kay suggest that morphological distribution is intended. Our data from Table 3 are relevant here. The undisputed basic terms in Russian each have more than to morphological derivations; we take this as our criterion and mark such terms with a tick in column (5) of Table 9. Those with between five and nine are marked with a '?', those with between one and four have '??' and those with no derivative at all are marked with ' $X$ '. The next subsidiary criterion (i.e. the sixth criterion overall) is that:

Color terms that are also the name of an object characteristically having that color are suspect, for example, gold, silver and ash (Berlin \& Kay, I969: 6). 
In Russian no term is truly identical to the name of an object, as adjectives are formed by suffixation. Nevertheless, in Russian a word such as rozovyj 'pink' is clearly related to the name of an object (roza means 'rose', see above) in a way that zelënyj 'green', for example, is not. Words derived in this way are marked in the sixth column with a?. The seventh criterion is that 'Recent foreign loan words may be suspect' (Berlin \& Kay, I969:6). We interpreted 'recent' quite broadly to mean 'within the last century'. We then scanned the dictionary by Dal' (published I $880-2$ ). All the terms are to be found in Dal', and so are not recent borrowings, with one exception. That is purpurnyj 'purple', which is certainly not a recent borrowing. Thus all the terms pass on this criterion. The eighth test, as previously mentioned, applies only to cases considered dubious by the first, and so is not included here.

From Table 9 it is clear that the first seven colour terms are basic, as they each fulfil all the above criteria. It is particularly interesting to note that both sinij 'dark blue' and goluboj 'light blue' qualify for basic-term status on these criteria. This confirms that Russian has two basic colour terms occupying the position on Berlin \& Kay's hierarchy corresponding to blue in English. Kay \& McDaniel $(1978: 640$ ) suggest that Russian may be in a state of flux as regards these two terms, with goluboj as a basic term for some speakers, but not for others. They add that:

The process that characterizes derived category formation has not been logically exhausted by any known language; so there is no apparent reason to believe that the process will not continue, extending basic color-term lexicons beyond their present eleven terms (Kay \& McDaniel, 1978:64I).

However, below goluboj the situation is unclear and it is by no means certain that Russian has reached this further stage posited by Kay \& McDaniel. Indeed, working from our data, Berlin \& Kay's criteria are not adequate for deciding which terms are basic. The Russian terms corresponding to purple present particular difficulties. It could even be argued that Russian has not yet developed a truly basic purple term.

It should be said that Berlin \& Kay take the first stage in research to be eliciting the basic colour terms from an informant (1969: 5). In view of the difficulty encountered with a language for which a good deal of data is available, it seems that such informant work would have to be extremely skilled, and this is perhaps a weak point in their approach, as is also noted by Conklin (1973: 936-937). Nevertheless, we intend to carry out informant work to attempt to clarify the troublesome areas identified in this study.

From the data presented, frequency in a range of texts is clearly a good predictor of basic colour terms. As already noted, it gives results which match the hierarchy almost perfectly, for the higher terms. Given that frequency counting is a straightforward test, it deserves more attention. It is tempting to suggest that this should be the only test and that it should be used to decide the unclear cases. This suggestion appears reasonable in the 
light of the data in Section 4. However, we must remember that, as stated in Section 2, some terms were excluded from consideration if they clearly violated one of the main Berlin \& Kay criteria. One such was ryžij 'ginger', which is normally predicated of hair (hence it is not basic because of the third criterion). It is nevertheless a frequent item, occurring 59 times in the Zasorina corpus, which makes it considerably more frequent than some of the basic terms. As might be expected, therefore, frequency cannot be the sole test; it is nevertheless a valuable indicator.

It is appropriate at this point to mention the results reported very briefly in Vasilevič (1982). He adopted the Berlin \& Kay criteria, and looked particularly at frequency and syntagmatic productivity. The top 20 colour terms on each test were compared, and those common to both lists ( 15 in all) were considered further. Of these, nine cause no surprise (belyj 'white', čërnyj 'black', seryj 'grey', krasnyj 'red', simij 'dark blue', zelënyj 'green', žëltyj 'yellow', goluboj 'light blue' and rozovyj 'pink'). Four more can be excluded by Berlin \& Kay's criteria. But both bagrovyj 'crimson' and alyj 'scarlet' remained (we excluded the latter as being in the semantic field of krasnyj 'red'). On the other hand, neither oranževyj 'orange' nor fioletovyj 'violet' appeared. As a result of these unexpected inclusions and exclusions Vasilevič considered the method unsatisfactory. As an alternative, he tried a psycholinguistic experiment in which 200 subjects were asked to give colour terms appropriate to five different situations (sunrise, by the sea, etc.). Twelve colours formed a leading group in terms of frequency of occurrence, namely the achromatic colours belyj 'white', čerrnyj 'black' and seryj 'grey', the colours of the rainbow, krasnyj 'red', oranževyj 'orange', žëltyj 'yellow', zelënyj 'green', goluboj 'light blue', sinij 'dark blue', fioletovyj 'violet', together with rozovyj 'pink' and koričnevyj 'brown'. More details of the experiment are given in Vasilevič (I98I).

\subsection{Internal reconstruction of colour terms}

In the last section it was stated that frequency counts are a good indicator of basic colour terms; certainly the frequency data match the hierarchy better than does the count of derivatives (Table 3). For ease of reference we give the ranking according to morphology (derived from Table 3 ) and that for frequency (Table 7) for comparison in Table 10.

The colour term that stands out is krasnyj 'red', which has considerably fewer derivatives than its place on the hierarchy would lead us to expect, yet has a perfectly consistent frequency ranking. Krasnyj is not the original Slavonic word for red. There is a word cervonnyj 'red, dark red', which is now rare, but which is found in dialects and whose cognates are found in other Slavonic languages. The root kras has the original meaning 'beauty', which survives in numerous derivatives, and even in some uses of krasnyj in modern Russian (hence Krasnaja ploščad' 'Beautiful Square' rather than 


\begin{tabular}{|c|c|c|c|c|c|}
\hline & $\begin{array}{l}\text { Morphological } \\
\text { rank }\end{array}$ & $\begin{array}{l}\text { Frequency } \\
\text { rank }\end{array}$ & & $\begin{array}{l}\text { Morphological } \\
\text { rank }\end{array}$ & $\begin{array}{c}\text { Frequency } \\
\text { rank }\end{array}$ \\
\hline belyj 'white' & I & 2 & seryj 'grey' & 8 & 7 \\
\hline I ërnyj 'black' & 3 & 1 & rozovyj 'pink' & 10 & 9 \\
\hline krasnyj 'red' & 7 & 3 & lilovyj 'lilac' & 11 & 13 \\
\hline zelënyj 'green' & 4 & 4 & foletovyj 'violet' & 12 & 12 \\
\hline žëltyj 'yellow' & 5 & 8 & oranzevyj 'orange' & $I_{4}$ & 15 \\
\hline sinij 'dark blue' & 2 & 5 & bagrovyj 'crimson' & 14 & 14 \\
\hline goltuboj 'light blue' & 6 & 6 & purpurnyj 'purple' & 16.5 & 16.5 \\
\hline buryj 'brown' & 9 & 11 & purpurovyj 'purple' & 16.5 & 16.5 \\
\hline koricnevyj 'brown' & 14 & 10 & & & \\
\hline
\end{tabular}

Table 10

Comparison of morphological and frequency ranking.

'Red Square'). Krasnyj as a colour term is attested early in the sixteenth century (Trubačev, 1985: 109). We suggest that the number of derivatives of a colour term is not therefore determined solely by its place on the hierarchy, but also by the length of time it has been established in the language. Krasnyj is indubitably a basic colour term, it has a frequency 'appropriate' to its position on the hierarchy, but it has not been established in the language for sufficient length of time to acquire the 'appropriate' number of derivatives.

This account is strengthened by a similar case outside the realm of colour terms. The original word for 'good' was dobryj, as is shown by the fact that cognates are found in other Slavonic languages. In modern Russian it is used mainly of people in the sense of 'kind', and in a large number of set phrases, such as dobroe utro 'good morning'. Its place as the general word for 'good' has been taken by xorošij, a word of uncertain origin, first attested in the fourteenth century (Kiparsky, 1975: 172). The relevant data on the two words are given in Table $I I$.

\begin{tabular}{ccc}
\hline & $\begin{array}{c}\text { Derivatives } \\
\text { (Worth et al.) }\end{array}$ & $\begin{array}{c}\text { Occurrences } \\
\text { (Zasorina) }\end{array}$ \\
\hline dobryj & 51 & 277 \\
xorosij & 12 & 535 \\
\hline
\end{tabular}

Table II

Terms for 'good' in modern Russian

It is evident that while xoroši has supplanted dobryj in frequency of usage (if the forms dobro and xorošo are included the difference is even more striking), it has not yet caught up in terms of morphological derivatives.

Returning to colour terms, we suggest that there is a further example of this phenomenon in our data. Koričnevyj 'brown' is supplanting buryj, but 
it still has many less derivatives (though in this case its stem structure is partially responsible). Once again the older term retains its superiority in the number of derivatives. ${ }^{16}$ We conclude that when there is a significant difference in ranking between the morphology and frequency counts, with morphology coming below frequency, this indicates an historical disturbance of the colour-term system. Thus the two tests together form a valuable tool in the internal reconstruction of colour terms, to add to the methods discussed in Berlin \& Kay (1969: 36-4I).

\subsection{How many basic terms has Russian?}

The data we have presented provide clues as to which Russian colour terms qualify for basic status. The following terms merit closer attention. Berlin \& Kay (1969: 99) allow the possibility of two basic Russian terms for blue, as do Kay \& McDaniel (1978: 640); this idea is supported by informant work by Daly (MS: 16-17). ${ }^{17}$ Our evidence reveals new arguments to support this view. Morphological findings (Table 3) show goluboj 'light blue' and sinij 'dark blue' to be individually capable of occupying a place on the hierarchy. This view is borne out by frequency data (Table 6). We therefore conclude that Russian has two blue terms, both of which are basic.

The situation in the brown section of the hierarchy is particularly interesting. Russian has two terms: koričnevyj and buryj. According to Frumkina (1979: 166) koričnevyj is technically orange low in brightness, while buryj is yellow low in brightness. Buryj is derivationally richer than koričnevyj and also scores higher in Zasorina's frequency count (Table 4) in all except the literary genre. However, other frequency counts (Table 5) show koričnevyj to be more common than buryj. As was suggested in the last section, it seems that koricnevyj, the newer term, is becoming more frequent. Buryj retains a strong foothold in the language partly through use in certain collocations (buryj med'ved' 'brown bear', buryj ugol' 'brown coal').

As already noted, a similar situation has been found to exist in French (Forbes, 1979), where brum, the older word for brown, is gradually being overtaken by marron, a word originally derived from the French word meaning 'chestnut'. We feel that there is a striking parallel between these two situations: in both languages the newer term (koričnevyj, marron) is based on a root still present in the modern language, while the older term (buryj, brun) has cognates in other Indo-European languages.

As to which term is basic in Russian, we accept the general view that

[16] The remaining mismatch is $2 \ddot{e} l t y j$ 'yellow'; as stated earlier, we have no explanation as to why it occurs less frequently than its place on the hierarchy would lead us to expect, even though the number of derivatives is consistent with its position.

[17] Our own preliminary informant work would seem to confirm Daly's view. Daly (MS: 58-59) also quotes an example from a chronicle (in turn from Sreznevskij) which suggests that both may have been basic as early as 1230 . 
koričnevyj is basic. Nevertheless, the evidence for buryj is such that its general disregard by other investigators is a little surprising. Buryj was found to be more frequent than koričnevyj in three of the six word-counts we consulted. However, it appears to be collocationally more restricted. It is interesting to compare the analysis of Hill; he separates out colour terms which are 'abstrakt' (which can be used freely irrespective of the referent) from those which are collocationally restricted. The abstracts are then subdivided into class I (vollabstrakt 'fully abstract'), which includes koričnevyj, and class I a (gebrauchsbeschränkt 'limited in use'), which includes buryj (I972: I48; see also 106-108 for examples). The conclusion we draw from the position of buryj is that it demonstrates that koričnevyj is not fully established as the basic term. Another striking fact is that koričnevyj and buryj are found to be less frequent than seryj 'grey' and rozovyj 'pink' (except in the Mandelshtam Concordance, where koričnevyj scores slightly higher than seryj). Even counting the two Russian brown terms as one aggregate score does not raise brown above the former two terms.

These data support the reservations about the position of brown raised by Allan (I986: 119). He suggests that a separate stage IV, the addition of brown, is suspect. If brown were treated as the intersection of black and red, then all the secondary colour terms added at stage vi would be intersections with red.

Finally, purple warrants close consideration; we have found five potential terms, each of which will now be discussed. The term used by Slobin in Berlin \& Kay, purpurnyj, is clearly a weak contender for basic-term status. The study by Worth et al. (Table 3) found no item morphologically derived from it. This term also fared badly in frequency studies (Table 6). The same arguments apply to purpurovyj 'purple', which seems to be a less frequent variant of purpurnyj. ${ }^{18}$ Frumkina \& Mixeev (I983:55n.) express puzzlement that purpurnyj should ever have been chosen as a basic term, and Vasilevič (1983: 10) finds that for many informants its semantic field overlaps with that of krasnyj 'red'. Vasilevič's presentation of the data sometimes lacks clarity, but our own preliminary enquiries using Russian-speaking informants seem to confirm that the two terms overlap. Interestingly, Conklin points out the wide range of colours covered by purple in English and suggests that

The wide range in color reference ... may well stem from the qualitative and quantitative variations in the actual dyestuffs used in the pre-aniline era. Therefore, the bluish-to-crimson 'zone' seems to indicate the range of achievable colors with the colorant purple (Conklin, 1973: 935).

[18] Hill confirms this and gives useful examples (1972: 72-77). Note that in his classification (discussed above with relation to buryj), purpurnyj and purpurovyj, like bagrovyj and bagrjanyj, are considered to be 'gebrauchsbeschränkt', while both fioletovyj and lilovyj count as 'vollabstrakt' (1972: 148). 
Hill (1972: 72-74) also discusses the origins of purpurnyj and purpurovyj and quotes dictionary entries which suggest that in modern Russian they are ambiguous, meaning deep red with or without a blue component. Lilovyj 'lilac' has more derived terms than any other 'purple' term (Table 3), but frequency data (Table 6) are less impressive. Frumkina \& Mixeev (1983: 62) find that it lacks a well-defined focal point (suggesting that it is not basic). Indeed many of their informants (I983:58) misunderstood the term, some thinking that it was a shade of green or yellow. This would suggest that it is not psychologically salient for the majority of speakers and therefore not a basic term. Bagrovyj 'crimson' has few morphological derivatives, but achieves a respectable score in frequency counts. As mentioned earlier, bagrovyj, like alyj 'scarlet', was one of the terms isolated by Vasilevič (1982: I24) when he applied the Berlin \& Kay criteria. He found this intuitively surprising, and suggests that it casts doubt on this method of establishing basic colour terms. Like purpurnyj, bagrovyj was found by Vasilevič (I983) to overlap to some extent with krasnyj 'red', and therefore to be partly included in the semantic field of that term.

Among other investigators, the most popular contender for the purple slot is fioletovyj 'violet'. Frumkina \& Mixeev include it in their list of basic terms to the exclusion of all other 'purple' terms discussed here. They find that informants generally agree about what constitutes the best example of foletovyj, and point out that this is in keeping with basic-term status ( $1983: 55,59,62)$. It is perhaps significant that when conducting experiments on childrens' use of colour terms, Istomina (r960a, b) also used only fioletovyj of the colour terms discussed. Vasilevič (1983: 10) is also favourably disposed to the term fioletovyj. However, although fioletovyj has almost as many derivatives (Table 3 ) as lilovyj 'lilac', and is found by Zasorina (Table 6) to be a relatively frequent item, it occurs mainly in Zasorina's non-fictional genre. This suggests that it does not fulfil the fourth of Berlin \& Kay's criteria for basicness discussed above, not occurring in the idiolects of all informants (Berlin \& Kay, 1969: 6). The somewhat restricted use of fioletovyj casts a shadow over its claim to basic status. ${ }^{19}$

To conclude, the choice of a Russian 'purple' term is far from straightforward. In informant work, Daly (MS: 24-39) found considerable confusion in this area. In Berlin \& Kay's terms, this comes as no surprise given that purple is at the bottom of the colour-term hierarchy. But it is perhaps also worth bearing in mind that purple can be interpreted as the intersection of red and blue (Kay \& McDaniel, 1978: 640). In a language

[19] An argument in favour of foletowy would be that it is one of the colours of the rainbow. They are krasnyj, oranževyj, žëlyyj, zelënyj, goluboj, sinij and fioletovyj, for which there is an amusing mnemonic: každyj oxolnik želaet znat', gde sidit fazam 'every hunter wants to know where the pheasant is'. However, this is a weak argument, since English indigo is also a colour of the rainbow but not a basic colour term (cf. Conklin, 1973: 939). 
such as Russian where, as we have shown here, there are two basic terms corresponding to blue, it may be that purple necessarily poses problems. This hypothesis would require further investigation. Of the five terms discussed here, it seems to us that the best contender for basic-term status is foletovyj. However, we put this term forward with some reservation, as is explained above. It appears that Russian possesses no purple term fully established as basic. The corollary of this argument would be that Russian has so far developed only in basic colour terms, with two blue terms, but no purple term. In this sense, Russian would not fit into the hierarchy originally presented by Berlin \& Kay.

\section{Conclusion}

We have demonstrated that the Berlin \& Kay hierarchy, which made claims about the possible sets of colour terms and therefore about the order in which languages acquire colour terms, is clearly reflected in the lexical structure of a language which has acquired a colour term for at least ten of Berlin \& Kay's eleven categories. It is reffected in two ways: terms higher up the hierarchy both occur more frequently than do those lower down, and have greater derivational possibilities. The match is not perfect, but it is remarkably close. Word frequency shows a better match than does morphology; when the two are out of step this may reveal something of the internal history of the colour terms, as it does in the case of krasnyj 'red'. Both tests reinforce the claim that simij 'dark blue' and goluboj 'light blue' are basic colour terms, thus confirming Russian as being of exceptional interest in having an 'extra' basic colour term.

Nevertheless problems remain. Seryj 'grey' does not behave as predicted by the original hierarchy, but it had already been established that grey may behave as a 'wild card'. The situation of korichevyj and buryj 'brown' is more interesting; the available evidence suggests that the two terms together fill the brown slot on the hierarchy. With purple the position is particularly confused. On the basis of existing evidence and of the criteria for determining basic colour terms, we are not yet able to decide for certain which, if any of the several Russian terms is the basic colour term occupying the 'purple slot' (though fioletovyj is the strongest contender). Thus the Berlin \& Kay hierarchy can be used to make predictions about the lexical structure of a single language, and these turn out to be largely valid in the case of Russian. It also highlights problems which would otherwise have gone unnoticed but which merit further investigation. Russian nevertheless remains problematic for the Berlin \& Kay hierarchy, having two basic terms for blue, while the status of the purple terms is still uncertain. 


\section{GREVILLE CORBETT AND GERRY MORGAN}

\section{REFERENCES}

Abakumova, A. et al. (1968), 2380 slov naibolee upotrebitel'nyx v russkoj razgovornoj reči. Moscow: Universitet družby narodov imeni Patrisa Lumumby, Kafedra russkogo jazyka. Agoston, G. A. (1979). Color theory and its application in art and design. Berlin: Springer.

Agoston, $\breve{Z}$. (1982). Teorija cveta $i$ ë primenenie v iskusstve $i$ dizajte. (Translation of Agoston (I979) by Penova, I. V.) Moscow: Mir.

Alimpieva, R. V. (1986). Semantičeskaja značimost slova i struktura leksiko-semantičeskoj gruppy: na materiale prilagatel'nyx-cvetooboznačenija russkogo jazyka. Leningrad: Izdatel'stvo Leningradskogo universiteta.

Allan, K. (1986). Linguistic meaming I-II. London: Routledge and Kegan Paul.

Andrick, G. R. \& Tager-Flusberg, H. (1986). The acquisition of colour terms. Journal of Child Language 13. 119-134.

Berlin, B. \& Kay, P. (1969). Basic color terms: their universality and evolution. Baltimore: University of California Press.

Conklin, H. C. (1973). Color categorization: review of Berlin, B. \& Kay, P. (1969). AmA 75 . $931^{-9} 942$.

Cruse, D. A. (1977). A note on the learning of colour names. Journal of Child Language 4. 305-311.

Cyganenko, G. P. (1970). Étimologičeskij slovar' russkogo jazyka. Kiev: Radjans'ka škola.

Dal', V. (I.) (1880 1882). Tolkovyj slovar' živago velikoruskago jazyka 1-1V. Facsimile edition (1978). Moscow: Russkij jazyk.

Daly, T. (MS.) Color terms in the Slavic languages. Berkeley: University of California.

Dictionary of Spoken Russian (1958). Dictionary of spoken Russian: Russian-English/ English-Russian. New York: Dover.

Dixon, R. M. W. (1982). Where have all the adjectives gone?: and other essays in semantics and syntax. Berlin: Mouton.

Esser, M. (1979). Etude comparative du lexique chromatique en français et en russe (d'après 'Vojna i mir' de Tolstoj et la traduction 'La guerre et la paix' de Boris de Schloezer). Le Langage et l' Homme 40. 43-7.

Evgen'eva, A. P. (1971). Slovar' sinonimov russkogo jazyka 1-1I. Leningrad: Nauka.

Falla, P.S. (1984). The Oxford English-Russian Dictionary. Oxford: Clarendon Press.

Forbes, I. (1979). The terms brum and marron in modern standard French. $J L$ 15. 295 305.

Frumkina, R. M. (1978). O metode izučenija semantiki cvetooznačenija (vvodnye zamečanija). Semiotika i informatika 10. 142-161.

Frumkina, R, M. (1979). Ob otnošenijax meždu metodami i ob"ektami izučenija v sovremennoj semantike (v sujazi s izučeniem semantiki cvetooboznačenij). Semiotika $i$ informatika 1 I. 149-174.

Frumkina, R. M. \& Mixeev, A. V. (1983). Vozmožnosti sopostavilel'nogo izučenija leksiki v èksperimente (na materialy russkix prilagatel'nyx-cvetooboznačenija). Sajpostavitelno ezikoznanie 8, 2, $51-63$.

Gal'perin, I. R. (1977). Bol'šoj anglo-russkij slovar' 1-II. Moscow: Russkij jazyk.

Hays, D. G., Margolis, E., Naroll, R. \& Perkins, D. R. (1972). Color term salience. AmA 74. I107-1121.

Heider, E. R. (1971). 'Focal' color areas and the development of color names. Developmental Psychology 4. 447-455.

Heider, E. R. (1972). Universals in color naming and memory. Joumal of Experimental Psychology 93. 10-20.

Heider, E. R. \& Olivier, D. (1972). The structure of the color space in naming and memory for two languages. Cognitive Psychology 3. 337-354.

Hill, P. M. (1972). Die Farbwörter der russischen und bulgarischen Schriftsprachen der Gegenwart (Versuch einer Klassification und einer struknurell-semantischen Analyse). Amsterdam: Adolph M. Hakkert.

Istomina, Z. M. (1960a). O vzaimootnošenii vosprijatija i nazyvanija cveta u detej doškol'nogo vozrasta (èksperimental'noe issledovanie). Isvestija Akademii pedagogičeskix nauk RSFSR. I13. $76-102$.

Istomina, Z. M. (1960b). Vosprijatie i nazvanie cveta v rannem vozraste. Isvestija Akademii 


\section{COLOUR TERMS IN RUSSIAN}

pedagogičeskix nauk RSFSR. 113. 103-1 1 3. TTranslated as Istomina, A. M. (1963). Perception and naming of color in early childhood. Soviet Psychology and Psychiatry I. 37-45.]

Judd, W. \& Wyszecki, G. (1963). Color in business, science and industry. New York: Wiley, and ed. (Ist ed. 1952).

Kay, P. (1975). Synchronic variability and diachronic change in basic color terms. Language in Society 4. 257-270.

Kay, P. \& McDaniel, C. K. (1978). The linguistic significance of the meanings of basic color terms. $\operatorname{Lg} 54.610-646$.

Kiparsky, V. (1975). Russische historische Grammatik 3. Heidelberg: Carl Winter Universitätsverlag.

Koubourlis, D. J. (ed.). (1974). A concordance of the poems of Osip Mande/stam. Ithaca: Cornell University Press.

Lacroix, J.-C. (1978). Notes sur l'emploi des termes de couleur en français. In Tornay, S. (ed.), Voir et nommer les couleurs. Nanterre: Laboratoire d'ethnologie et de sociologie comparative. $181-206$.

McNeill, N. B. (1972). Colour and colour terminology. Journal of Linguistics 8. 21-33.

Mathiot, M. (1979). Folk definitions as a tool for the analysis of lexical meaning. In M. Mathiot (ed.), Elhnolinguistics: Boas, Sapir and Whorf revisited. Mouton: The Hague. 122-26o.

Menn, L. \& MacWhimney, B. (1984). The repeated morph constraint: toward an explanation. Lg 60. 519-540.

Meunier, Annie (1978). La couleur et ses termes en français. In Tornay, S. (ed.), Voir et nommer les couleurs. Nanterre: Laboratoire d'ethnologie et de sociologie comparative. 167-I69.

Moskovič, V. A. (1969). Statistika i semamtika: Opyt statističeskogo analiza semantičeskogo polja. Moscow: Nauka.

Müller, V. K. (1965). Anglo-russkij slovar': 7000o slov i yyraženij, I th ed. Moscow: Sovetskaja ènciklopedija.

Ožegov, S. I, \& Šapiro, A. B. (eds) (I959). Orfografičeskij slovar' russkogo jazyka. Moscow, 4th ed. (quoted from Worth et al., 1970).

Pap, A. (1957). Once more: colors and the synthetic a priori. Philosophical Review' 66. 94-99.

Pelevina, N. F. (1962), O sootnošenii jazyka i dejstvitel'nosti: (oboznačenie krasnogo i sinego cvetov). Filologičeskie nauki 2. 149-152.

Polubichenko, L. V. \& Shkhvatsabaja, T. (1985). The topology of colour terms. Quinquereme 8. 53-61.

Putnam, H. (1956). Reds, greens and logical analysis. Philosophical Review 65. 206-217.

Putnam, H. (1957). Red, and green all over again: a rejoinder to Arthur Pap. Philosophical Review 66. 100-106.

Rabkin, E. B. (1956). Atlas cvetov. Moscow, Gosudarstvennoe izdatel'stvo medicinskoj literatury (Medgiz).

Rabkin, E. B. (1962). Polixromatičeskie tablicy dlja issledovanija cvetooščuščnija. Moscow: Izdatel'stvo medicinskoj literatury, 7 th ed. (ist ed. 1936).

Senft, G. (forthcoming). Kilivila colour terms. To appear in Studies in Language Ir. (1987).

Smirnitsky, A. I. (1965). Russko-anglijskij slovar': okolo 50,000 slov. Moscow: Sovetskaja ènciklopedija.

Štejnfel'dt, E. A. (1963). Častomyj slovar' souremennogo russkogo literattrnogo jazyka: 2500 naibolee upotrebitel'nyx slov: Posobie dlja prepodavatelej russkogo jazyka. Tallin: Naučnoissledovatel'skij instilut pedagogiki Éstonskoj SSR.

Thurnwald, R. (1922). Psychologie des primitiven Menschen. Munich (quoted from Pelevina, 1962).

Tixonov, A. N. (1985). Slovoobrazovatel'nyj slovar' russkogo jazyka I-II. Moscow: Russkij jazyk.

Tornay, S. (ed.) (1978). Voir et nommer les couleurs. Nanterre: Laboratoire d'ethnologie et de sociologie comparative.

Trubačev, O. N. (1985). Ėtimologiceskij slovar' slavianskix jazykov. I2. Moscow: Nauka.

Vasilevič, A. P. (1981). Oboznačenie creta v souremennom russkom jazyke. Moscow (quoted from Vasilevič, 1983).

Vasilevič, A. P. (1982). 'Osnovnye' cvetonaimenovanija: konstrukt ili psixolingvističeskaja real'nost? Materialy V/ll vesojuznogo simposituma po psixoling vistike. Moscow, 1982.

Vasilevič, A. P. (1983). Psixolingvističeskij podxod k ustanovleniju leksiceskix soolvetstvij (na 


\section{GREVILLE CORBETT AND GERRY MORGAN}

materialy bolgarskix, russkix i anglijskix cvetonaimenovanij). Săpostavitel'no ezikoznanie 8. $5-17$.

Vasmer, M. (1953). Russisches etymologisches Wörterbuch, 1-m. Heidelberg: Carl Winter Universitätsverlag.

Vinogradov, V. V., Barxudarov, S. G., Blagoj, D. D. \& Tomaševskij, B. V. (eds) (1956-61). Slovar' jazyka Puškina, I-IV plus appendix. Moscow: Gosudarstvennoe izdatel'stvo ino strannyx i nacional'nyx slovarej.

Wade, T. L. B. (1985). Colour phraseology in contemporary Russian. Joumal of Russian Studies 49. $48-59$.

Wheeler, M. (1984). The Oxford Russian-English dictionary, and ed. Oxford: Clarendon Press.

Wilson, Elizabeth A. M. (1982). The modern Russian dictionary for English speakers. Moscow: Pergamon Press and Russian Language Publishers.

Wilson, N. L. (1972). Color qualities and reference to them, CJL 2. 145-169.

Witkowski, S. R. \& Brown, C. H. (1977). An explanation of color nomenclature universals. American Ethologist 79. 50-57.

Worth, D. S., Kozak, A. S. \& Johnson, D. B. (1970). Russian derivational dictionary. New York: American Elsevier.

Wright, W. D. (1969). The measurement of colotr. London: Adam Hilger, $4^{\text {th }}$ ed. (Ist ed. 1944).

Zasorina, L. N. (ed.) (1977). Častomyj slovar' russkogo jazyka: okolo 40000 slow. Moscow: Russkij jazyk.

Zollinger, H. (1976). A linguistic approach to the cognition of colour vision in man. Folia Linguistica 9. 265-293. 